\section{Kastamonu Eğitim Dergisi Kastamonu Education Journal}

Mayıs 2019 Cilt:27 Sayı:3

kefdergi.kastamonu.edu.tr
Başvuru Tarihi/Received: 27.04.2018

Kabul Tarihi/Accepted: 27.06.2018

DOI: 10.24106/kefdergi.3022

\title{
STEM Eğitimine Yönelik Umut ve Hedefler Ölçeği Uyarlaması: Geçerlik ve
} Güvenilirlik Çalışması

\section{Adaptation of Hopes and Goals Survey for STEM Education: Validity and Reliability Study}

\section{Öz}

\author{
Sülayman YAMAN ${ }^{1}$, Aslı SARIŞAN TUNGAÇ², Belgin BAL INCEBACAK ${ }^{3}$
}

Çalışmanın amacı, ortaokul öğrencilerinin STEM eğitimine yönelik umut ve hedeflerini belirlemek amacıyla geçerlik ve güvenirlik düzeyi yüksek bir ölçme aracı geliştirmektir. Araştırma, Douglas ve Strobel tarafindan geliştirilen ve 19 maddeden oluşan STEM Eğitimine Yönelik Umut ve Hedefler isimli ölçeğin Türkçeye uyarlamasının yapıldığı metodolojik geçerlik ve güvenirlik çalışmasıdır. Araştırmanın örnekleminde, 12 farklı ortaokulun 5-8. sınıflarında öğrenim gören toplam 873 öğrenci yer almıştır. Ölçme aracının faktör yapısını ve bu yapının uygunluğunu test etmek için Açımlayıcı Faktör Analizi (AFA) ve Doğrulayıcı Faktör Analizi (DFA) yapıımıştır. Hem AFA hem de DFA sonuçları, uyarlanan ölçeğin dört faktör üzerine kurulabileceğini göstermektedir. Farklı yöntemler kullanılarak bu sonuçlar test edilmiştir. Ayrıca DFA analizine göre uyum indeksleri, ölçme aracının faktörleri doğruladığını göstermektedir. İki farklı örneklem grubundan elde edilen verilerin güvenirlik katsayılarının kabul edilebilir düzeyde olduğu belirlenmiştir. Ölçeğin alt faktörleri "okulda öğrenme umudu ve iş doyumu umudu", "fene yönelik tutum", "mühendisliğe yönelik tutum" ve "matematiğe yönelik tutum" şeklindedir. Bu çalışmanın sonuçları ölçeğin güvenirlik ve geçerlik yönünden uygun olduğunu ve özellikle ortaokul düzeyinde kullanılabileceğini göstermektedir.

Anahtar Kelimeler: ölçek uyarlama, STEM eğitimi, umut ve hedef

\section{Abstract}

The aim of the research is to develop a measurement tool with a high level of validity and reliability to determine the hopes and goals for STEM education of the students. This is a methodological validity and reliability study in which the Turkish version of the Hopes and Goals Survey for STEM Education developed by Douglas and Strobel and consisting of 19 items is adapted. The sampling of this research consisted of 873 students from 5-8 grades of 12 different secondary schools. Exploratory Factor Analysis (EFA) and Confirmatory Factor Analysis (CFA) were conducted to test the factor structure of the measurement tool and the suitability of this structure. Both EFA and CFA results show that the adapted survey can be established on four factors. These results were tested using different methods. Furthermore, according to the CFA analysis, fit indices show that the measurement tool confirms the factors. It was determined that the reliability coefficients of data obtained from two different sample groups were acceptable. The sub-factors of the survey are "hope for learning at school and hope for job satisfaction", "attitude towards science", "attitude towards engineering" and "attitude towards mathematics". The results of this study show that the survey is suitable in terms of reliability and validity, and that it can be used especially at the secondary school level.

Keywords: survey adaptation, STEM education, hopes and goals

1. Ondokuz Mayıs Universitesi, Eğitim Fakültesi, Samsun, Türkiye; https://orcid.org/0000-0001-5152-4945

2. Ondokuz Mayıs Universitesi, Eğitim Fakültesi, Samsun, Türkiye; https://orcid.org/0000-0003-3709-5288

3. Ondokuz Mayıs Universitesi, Eğitim Fakültesi, Samsun, Türkiye; https://orcid.org/0000-0003-4643-8051

Atff / Citation: Yaman, S., Sarışan Tungaç, A.,\& Bal İncebacak, B. (2019). STEM eğitimine yönelik umut ve hedefler ölçeği uyarlaması: geçerlik ve güvenilirlik çalışması.Kastamonu Education Journal, 27(3), 1257-1271. doi:10.24106/kefdergi.3022 


\section{Extended Summary}

Purpose and Significance: In STEM Turkey Education Report, it is emphasized that various studies should be conducted on entrepreneurship in Turkey (STEM-Entrepreneurship, STEM+E), art/design (STEM-Art, STEAM) and programming (STEM-Computing, STEM+C). The number of studies on STEM education, which is a new topic in the world and our country, has been increasing rapidly. This situation also increases the need for measurement tools having high validity and reliability. Yılmaz, Yiğit-Koyunkaya, Güler, and Güzey (2017) conducted a scale adaptation study to determine the attitudes of secondary school students in terms of STEM education. The STEM Awareness Scale (Buyruk and Korkmaz, 2016) for university students is another measurement tool developed for STEM education. The presence of a measurement tool for the determination of hopes and goals of students in terms of STEM education will have significant contributions to the national literature on the relevant subject. For this reason, the Turkish adaptation, validity and reliability studies of the survey "Hopes and Goals for Elementary STEM Education" developed by Douglas and Strobel (2015) were conducted in this study. The lack of any other measurement tool for determining the hopes and goals of STEM education in primary school, secondary school and high school students in the national literature supports the uniqueness of this research.

Methodology: Since this research is a survey adaptation study, it is a methodological validity and reliability study. The sampling of the research consists of 873 (202 EFA sampling, 671 CFA sampling) secondary school students studying in the central districts of three different provinces in the Black Sea Region during the fall and spring semesters of 2016-2017. Convenience sampling method was used in the research as an improbable sampling method. The Hopes and Goals Survey for K-12 STEM Education to be adapted was developed by Douglas and Strobel in 2015 and has 19-items and a five-factor structure. The adaptation of the survey into Turkish and the validity and reliability studies were conducted according to the scale adaptation stages specified by Seçer (2015). Hopes and Goals Survey was translated into Turkish by two field specialists and an English language expert. The translated version was examined by 2 different linguists and 1 sociologist for its compatibility with the original survey. At this stage, cultural appropriateness as well as the comprehensibility of the items was examined, and the Turkish form of the survey was prepared. In the third stage, survey items were translated one more time into English by two different instructors of English Language and Literature. The Turkish version of the survey, the form translated back into English, and the original survey form were evaluated by two academicians. In addition, the final shape of Turkish survey was given by taking the opinions of one faculty member from the fields of Measurement and Evaluation, Educational Programs, and Teaching. Assessments for compatibility in terms of linguistic, cultural, structural and content aspects were completed with the completion of these stages. Exploratory and confirmatory factor analyses were performed to reveal the structural validity. Both internal consistency coefficient and test retest reliability were calculated to determine the reliability of the survey.

Results: In this study conducted to develop a valid and reliable survey for displaying the Hopes and Goals for STEM education, EFA method revealed a 4-factor structure consisting of 18 items. These factors were; "hope for learning in school and hope for job satisfaction", "attitude towards science", "attitude towards engineering" and "attitude towards mathematics". First factor consisted of eight items (1-2-3-4-5-7-8-9), second factor of three items (10-11-12), third factor of four items (14-15-16-17), and the fourth factor consisted of three items (18-19-20). The Cronbach Alpha coefficient calculated for the entire survey was 0.86 ; and the coefficients for each factor were 0.79 for "hope for learning in school and hope for job satisfaction", 0.91 for "attitude towards science", 0.87 for "attitude towards engineering", and 0.92 for "attitude towards mathematics". The reliability values obtained for the whole survey and the factors were above 0.70 , which is accepted as the coefficient threshold value in scales. The internal consistency coefficients obtained from the whole survey and from the factors were very close to the confidence interval and above the ideal reliability value. The reliability coefficients obtained present that the survey is reliable. Because of the test re-test analysis, the correlation coefficient was calculated as .95. The relevant finding suggests that the survey gives consistent results when applied at different times. As the result of the validity and reliability analyses performed, "hopes and goals survey related to STEM education" consisting of 18 items and 4 sub-factors was developed. It is believed that this survey will contribute to the studies on determining the hopes and goals of secondary school students for STEM education.

Discussion and Conclusion: It is believed that the Hopes and Goals Survey adapted and the validity and reliability analyses of which were conducted within the scope of this research, will be a guide and determinant in the studies to be conducted on STEM, entered curricula and being a popular topic in Turkey as much as it has been in the world in recent years. It is thought that this survey can be used to receive useful information in terms of affective dimensions of researchers, teachers, and the students expected to be mostly affected by STEM. Even though cognitive dimension of learning is highly significant, teaching or learning without taking the affective dimension into account is impossible (Özden, 2002). New studies on how and how much these affective and cognitive skills affect each other in STEM-related learning are required. Based on the results of these studies, establishing a theoretical framework regarding the level of realization of the targets set for STEM education may be expected. 


\section{Giriş}

Eğitim, belki de dünyada en fazla tartşılan ve üzerinde çalışma yapılan konulardan biridir. Çünkü tüm dünyada hemen hemen herkes doğrudan veya dolaylı şekilde eğitim sürecinin bir parçasıdır. Formal veya informal eğitim doğumdan ölüme kadar günümüz insanlarının bir şekilde bağlantılı olduğu kavramlardır. Özellikle 1800'lü yılların sonundan itibaren öğrenme üzerine yapılan çalışmalar birçok yeni kavramın bu sürece dâhil olmasına neden olmuştur. Davranış̧̧ı Kuram, Gestalt Kuramı, Bilgiyi İşleme Kuramı, Tam Öğrenme Kuramı, Bilişselci Kuram, Zihinsel Yapılanma Kuramı, en önemli kuramlar arasında yerlerini almıştr. 2000'li yıllarla birlikte Yapılandırmacı Kuram tüm dünyada olduğu gibi Türkiye'de de çok ilgi çeken ve birçok araştırmacının üzerinde durduğu bir eğitim kuramı olarak karşımıza çıkmıştr. Elbette bu kuramların hiçbiri birbirinden bağımsız veya ilişkisiz değildir. Bu kuramlar arasında güçlü bağlar ve birbirini tamamlayan birçok nokta bulunmaktadır. Bu kuramlarla birlikte aktif öğrenme, problem çözme, işbirlikli öğrenme, keşfetme ve araştırma, kavram öğrenme, disiplinler arası öğrenme gibi birçok bilgi ve anlayış eğitim literatüründe yerini almıştır. Bunların yanında son yılların en önemli eğitim kavramlarından biri STEM eğitim anlayışı (Fen-Science, Teknoloji-Technology, Mühendislik-Engineering ve Matematik-Mathematics) olmuştur. Disiplinler arası öğrenmeye yeni bir bakış açısı kazandıran STEM eğitimi, eğitimcilerin yanında siyasetçi ve iş dünyasının da ilgisini çekmiştir. STEM eğitiminin sonuçlarına yönelik beklentilerin yüksek olması konunun en fazla ele alınan kavramlardan biri olmasına neden olmaktadır.

\section{STEM Eğitimi}

Birçok çalışmada eğitim olarak adlandırılan STEM, (Akgündüz, Aydeniz, Çakmakçı, Çavaş, Çorlu, Öner ve Özdemir, 2015), hızla gelişen dünyada disiplinler arası etkileşimin ve bilgi birikiminin artması ile popülerlik kazanmıştr. Çünkü hızla artan bilginin içinde üreten, sorgulayan, farklı bakış açılarına sahip, eleştirel ve yaratıcı düşünen bireylere ihtiyaç duyulmaktadır (Bağcı ve Şahbaz, 2012). Bu nedenle eğitim-öğretim programları yeniden yapılandırılmış ve eğitim sürecinde farklı uygulamaların yapılması zorunluluk halini almıştı. Birden fazla disiplini içermesi (Scott, 2009:3) ve 21. yüzyıl ihtiyaçlarına yönelik olması nedeniyle en yeni uygulamalardan biri olan STEM ortaya çıkmıştı (Langdon, McKittrick, Beede, Khan ve Dom, 2011:2). STEM eğitimine yönelik ilk çalışma 2001 yılında The National Science Foundation yöneticisi olan Judith A. Ramaley'e aittir. Daha sonra bu eğitim anlayışına yönelik çalışmalar çok hızlı bir şekilde yaygınlaşmıştır (Yıldırım ve Altun, 2015:238).

Friedman (2005) toplumların gün geçtikçe daha fazla teknoloji temelli bilgiye gereksinim duyduğunu ifade etmiştir. Lubinski ve Benbow (2006) ise insanların uğraştkları fiziksel ve sosyal sistemlerin daha karmaşık ve dinamik hale geldiğini belirtmişlerdir. Bu durum yoğun rekabetin olduğu günlük yaşamda ayakta kalabilmenin daha da güçleşmesine neden olmaktadır. Birçok iş alanının yok olması, üretimde insan gücünün yerini makinelerin ve robotların alması, teknolojinin ve bilgi birikiminin olağanüstü artması gibi nedenler ülkeleri yönetenlerin, var olan güçlerini korumak veya dünyada söz sahibi olabilmek için önemli reformlara ihtiyaç olduğunun farkına varmalarına neden olmuştur. Amerika Birleşik Devletleri (ABD) Eski Başkanı Barack Hussein Obama 2009 yılında yapttğı konuşmada, dünya liderliğini korumak ve yeni yüzyılın güçlükleri ile mücadele etmek için eğitimde on yıllık bir eylem planı hazırladıklarını ifade etmiştir (The White House, 2009). Bu konu ile ilgili Obama (2010) bir konuşmasında şunları söylemiştir: "...Geleceğin liderliği, öğrencilerimizi özellikle fen, teknoloji, mühendislik ve matematik (STEM) alanlarında nasıl eğiteceğimize bağlıdır". Bu eğitimin ana teması STEM'dir. Amerika'nın yanı sıra Almanya, İngiltere ve Finlandiya gibi ülkelerin yöneticileri de eğitim sistemlerini STEM eğitimine göre yapılandırmaktadırlar.

STEM eğitimi alan birey, bilim ve bilimin doğasına uygun olarak edindiği bilgileri kendisinde var olan şemaları düzenlemede kullanır. Günlük hayatında karşısına çıkan problem durumlarında edindiği bilgileri kullanarak çözümler arar (Baenninger ve Newcombe, 1989), yorum yapar (Yıldırım ve Altun, 2015:239), ilişkileri fark eder, çıkarımlarda bulunur (Wai, Lubinski ve Benbow, 2010) ve değerlendirmeler yapar. Bu durum öğrencilerin birçok yeni beceri kazanmasına katkı sağlar. STEM eğitimi öğrencilerin fene yönelik tutumlarını (Furner ve Kumar, 2007) ve öz yeterlilik becerilerini de geliştirir (Güneş ve Karaşah, 2016:130). STEM eğitimi, okul öncesinden lisansüstü düzeye kadar farklı yaş gruplarındaki öğrencilere hitap etmektedir. Okul öncesi ve ilkokul döneminde STEM eğitiminin temelleri atılır. Ortaokul döneminde bu eğitimler sonucunda öğrenciler öğrendikleri becerileri kullanma imkânı elde ederler. Lise seviyesinde meslek seçiminde gerekli yönlendirmeleri alırlar ve üniversite seviyesinde disiplinler arası çalışmalar yaparak mesleki beceriler kazanırlar (Pawlowski, 2007).

\section{Umut (Hope) ve Hedefler (Goal)}

Türk Dil Kurumu (TDK, 2017) umudu, ummaktan doğan duygu, olması beklenilen veya olacağı düşünülen şey, ümit şeklinde tanımlamaktadır. Snyder, Irving ve Anderson, (1991:287) umudu, etkileşimli olarak ortaya çıkan ve başarıı olma duygusunu temel alan olumlu bir motivasyon durumu olarak tanımlamışlar ve iki temel öğesi olduğunu belirtmiş- 
lerdir: Amaç-goal (hedefe yönelik enerji)i b) yol-pathways (hedefleri karşılamayı planlama). Bir başka tanımda ise umut, amaç (hedef yönelimli tanımlama) ve yolların (hedeflere ulaşma hedefleri) karşılıklı bir şekilde başarma duyusunu temel alan bilişsel bir düzenleme olarak ifade edilmiştir (Snyder, Harris, Anderson, Holleran, Irving, Sigmon ve diğ., 1991). Umut ve hedef kavramları incelendiğinde; umut, gelecek ile ilgili bir amacı gerçekleştirmede sıfirdan fazla olan beklenti şeklinde tanımlanmaktadır (Rideout ve Montemuro, 1986).

Douglas ve Strobel (2015) umudun çok farklı derinlikte olabileceğini ifade etmişlerdir. Örneğin birinin yağmur yağacağını umut etmesi ile kanser tedavisi gören başka birinin kemoterapinin hastalığına iyi geleceğini umut etmesinin düzeyi birbirinden oldukça farklıdır. Umut teorisinde ortaya konulan hedefler (goal), davranışlara motive olmak için oldukça önemli olmalıdır. Ayrıca, belirli bir hedefin ulaşılabilir olması ve gerçekleşmesi konusunda belirli ölçüde belirsizlik taşıması gerekir. Bir hedefe gerçekten ulaşılamaması, insanın her zaman moralinin düşmesine neden olur (Snyder ve Rand, 2000). Bir eylemin gerçekleşmesi için insanlar, hedeflerine ulaşmak için deneyecekleri yollar (pathways) olduğunu bilmelidirler. Bir kişi bir hedefe ulaşmak için bir yolu denediğinde engelle karşılaştırsa, alternatif yollar olduğunu öngörebilmelidir. Aksi takdirde kişi umut etmeyi bırakacaktır. Araştrrma sonuçları, umut düzeyi yüksek bireylerin düşük umutlu kişilere göre daha fazla alternatif yol üretebileceklerine yönelik algılarının yüksek olduğunu göstermektedir (Irving, Snyder ve Crowson, 1998; Snyder, 1994). Bu nedenle, eğitim sistemimizde yaygın bir şekilde yer almaya başlayan STEM eğitiminin hem Millî Eğitim Bakanlığı'nın hedefleri hem de bireylerin umut ve hedeflerini ne ölçüde karşıllayacağına yönelik teorik çerçevesinin oluşturulması yanında bu hedeflere yönelik bir alt yapının hazırlanmasına intiyaç vardır. Böylece STEM eğitimi ile öğrencilerin sadece öğrenmenin bir yolu olarak değil aynı zamanda gelecek yaşamları için umut kaynağı olacağı; aynı zamanda bu eğitimin bir yaşam biçimi olarak okuldaki başarı ve fene yönelik tutum için de bir hedef meydana getireceği söylenebilir (Douglas ve Strobel, 2015).

\section{Araştırmanın problemi}

STEM Türkiye Eğitim Raporunda Türkiye'de girişimcilik (STEM-Entrepreneurship, STEM+E), sanat/tasarım (STEM-Art, STEAM) ve programlama (STEM-Computing, STEM+C) kapsamında çeşitli çalışmalar yapılması gerektiğine vurgu yapılmıştır. Dünya ve ülkemiz için yeni bir konu olan STEM eğitimine yönelik çalışmaların sayısı her geçen gün artmaktadır. Bu durum, geçerlik ve güvenirliği yüksek ölçme araçlarına olan ihtiyacı da artırmaktadır. Yılmaz, Yiğit-Koyunkaya, Güler ve Güzey (2017) ortaokul öğrencilerinin STEM eğitimine yönelik tutumlarını belirlemek amacıyla bir ölçek uyarlaması yapmışlardır. Üniversite öğrencilerine yönelik STEM Farkındalık Ölçeği (Buyruk ve Korkmaz, 2016) ise, STEM eğitimine yönelik geliştirilen ölçme araçlarından bir başkasıdır. Öğrencilerin STEM eğitimine yönelik umut ve hedeflerinin belirlenmesine yönelik bir ölçme aracının olması, ilgili konuda ulusal literatüre önemli katkılar sağlayacaktır. Bu nedenle bu araştrmada Douglas ve Strobel tarafindan (2015) yılında geliştirilen “Hopes and Goals for Elementary STEM Education" ölçeğinin Türkçeye uyarlama, geçerlik ve güvenirlik çalışmaları gerçekleştirilmiştir. Ulusal alanyazında ilkokul, ortaokul ve lise düzeyinde öğrenim gören öğrencilerin STEM eğitimine yönelik umut ve hedeflerini ortaya koyan başka bir ölçme aracının bulunmaması, bu araştırmanın özgünlük boyutunu desteklemektedir.

\section{Yöntem}

Araştırma bir ölçek uyarlama çalışması olduğundan metodolojik geçerlik ve güvenirlik çalışmasıdır. Bu kapsamda örneklemden veri toplamada kesitsel tarama yöntemi kullanılmıştır (Karasar, 2005). Örneklemden toplanan veriler Şekil 1'deki işlemler takip edilerek amaca uygunluk ve tutarlılık açısından incelenmiş ve sistematik bir şekilde analiz edilmiştir.

\section{Örneklem:}

Araşttrmanın örneklemini 2016-2017 güz ve bahar dönemlerinde Karadeniz bölgesinde yer alan üç farklı ilin merkez ilçelerinde öğrenim görmekte olan toplam 873 (202 AFA örneklemi, 671 DFA örneklemi) ortaokul öğrencisi oluşturmaktadır. Araştırmada olasılıksız örnekleme yöntemlerinden elverişli örnekleme yöntemi kullanıımıştır. Milli Eğitim Müdürlüklerinde alınan izinlerin ardından belirlenen okullar içerisinden rastgele 12 ortaokul seçilmiş ve veriler bu okullarda öğrenim gören öğrencilerden gönüllülük esasına göre toplanmıştır. Araştırmanın örneklem grubuna ilişkin betimsel istatistikler Tablo 1'de verilmiştir.

Tablo 1. Araştırmanın örneklemine ilişkin betimsel istatistikler

\begin{tabular}{lcccccc}
\hline & Değişken & AFA & \multicolumn{2}{c}{ DFA } & N & \% \\
\hline \multirow{2}{*}{ Cinsiyet } & Kız & 101 & 50.0 & 363 & 54.1 & 45.9
\end{tabular}

| Kastamonu Eğitim Dergisi, 27(3), 2019| 


\begin{tabular}{lccccc}
\hline & Değişken & AFA & & DFA & N \\
\hline & 5. sınıf & 45 & 22.3 & 122 & 18.2 \\
Sınıf düzeyi & 6. sınıf & 52 & 25.7 & 177 & 26.4 \\
& 7. sınıf & 54 & 26.7 & 178 & 26.5 \\
\hline Toplam & 8. sınıf & 51 & 25.2 & 194 & 28.9 \\
\hline
\end{tabular}

\section{Veri Toplama Aracı}

STEM Eğitimine Yönelik Umut ve Hedefler Ölçeği-SEYUH (Hopes and Goals Survey for K-12 STEM Education-HAG) Douglas ve Strobel tarafindan 2015 yılında geliştirilmiştir. Araştırmacılar çalışmalarının amacını, eğitim sürecinin 12 yıllık döneminde olan öğrencilerin STEM eğitimine yönelik umut ve hedeflerini ortaya koyacak geçerlik ve güvenirliği yüksek bir ölçme aracı geliştirmek olarak belirtmişlerdir. Araştırmacılar var olan umut ölçeklerini incelemişler ve Snyder ve Rand (2000)'in kuramsal çerçevesine bağlı kalarak madde yazımını gerçekleştirmişlerdir. Likert tipinde hazırladıkları ölçeğin yapı geçerliğini belirlemek için 265 öğrenciden veri toplamışlardır. AFA ile ilk olarak on faktörlü bir yapı meydana geldiğini belirlemişlerdir. Uygun olmayan maddeler ölçekten çıkarıldıktan sonra 20 maddeden oluşan bir yapının meydana geldiğini ortaya koymuşlardır. Bu maddeler üzerinde yapılan işlemlerde 1 maddenin iki farklı faktörde binişiklik gösterdiğini belirlemişler ve bu maddeyi çıkararak 19 maddeden oluşan beş faktörlü nihai ölçeğe son çeklini vermişlerdir. Bu faktörlere sırasıyla "okulda öğrenme umudu", "iş doyumu umudu", "fene yönelik tutum", "matematiğe yönelik tutum" ve "mühendisliğe yönelik tutum" isimlerini vermişler ve her bir faktörün iç tutarlıık katsayısını 0.63, $0.87,0.73,0.91$ ve 0.78 olarak bulmuşlardır. Ölçeğin tamamının iç tutarlılık katsayısı ise 0.82 'dir. Elde edilen bu faktör yapısını DFA ile incelemişler ve uyum indekslerinin yeterli olduğunu ifade etmişlerdir. Likert tipteki ölçme aracının maddelerine verilecek beş dereceli yanıtlar Kesinlikle Katılıyorum-Kesinlikle Katılmıyorum aralığındadır.

\section{Ölçek Uyarlama Çalışmasının Aşamaları}

Alanyazındaki STEM eğitimine yönelik ölçme aracı ihtiyacının tespit edilmesinin ardından, literatür taranmış ve ilgili ölçekler incelenmiştir. Bu kapsamda incelenen SEYUH Ölçeğinin bu amaca uygun olduğu belirlenerek ölçeği geliştiren araştrrmacılardan uyarlama yapmak için gerekli izinler alınmıştr. Ölçeğin Türkçeye uyarlanması ve geçerlik, güvenirlik çalışmaları için Seçer (2015)'in belirtmiş olduğu aşağıdaki aşamalar dikkate alınmıştır:

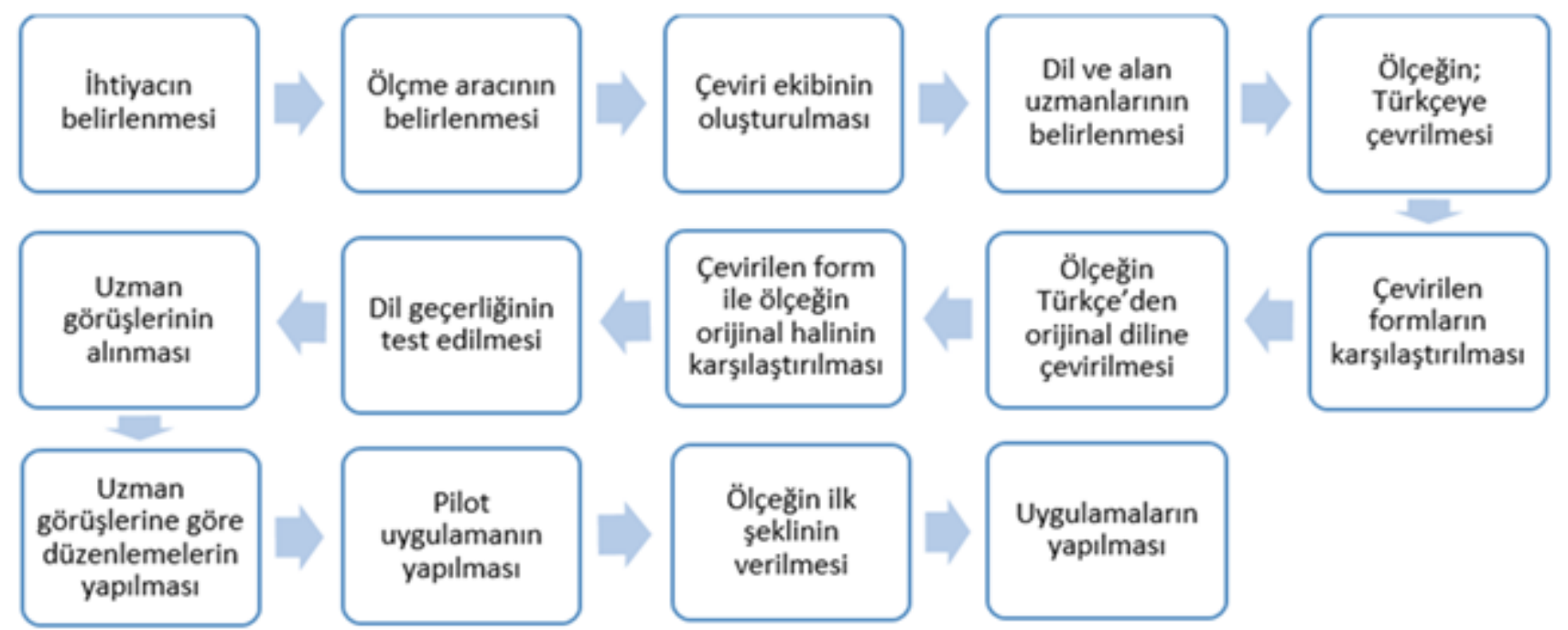

\section{Şekil 1. Ölçek geliştirme süreç aşamaları}

\section{SEYUH Ölçeğinin Türkçeye Uyarlanması}

SEYUH'un Türkçeye uyarlanmasında izlenen aşamalar sırasıyla şu şekildedir: Illk çevirinin yapılması, ilk çevirinin değerlendirilmesi, çevirinin yeniden orijinal dile çevrilmesi, orijinal dildeki çevirinin değerlendirilmesi ve uzmanların görüşlerinin alınmasıdır. Bu bağlamda öncelikle çeviri ekibi oluşturulmuştur. SEYUH iki alan eğitimi uzmanı ve bir İngiliz Dili uzmanı tarafindan Türkçeye çevrilmiştir. Bu çeviri 2 farklı dil uzmanı ve 1 sosyolog tarafindan incelenerek orijinal ölçekle uyumuna bakılmıştır. Bu aşamada maddelerin anlaşılırlığı yanında kültürel uygunluk da incelenmiş ve ölçeğin Türkçe formu hazırlanmıştı. Üçüncü aşamada ölçek maddeleri 2 farklı İngiliz Dili ve Edebiyat öğretim elemanı tarafindan yeniden İngilizceye çevrilmiştir. Ölçeğin Türkçe formu, yeniden İngilizceye çevrilen formu ve orijinal ölçek formu iki 
öğretim elemanı tarafindan değerlendirilmiştir. Ayrıca Ölçme ve Değerlendirme, Eğitim Programları ve Öğretim alanlarından birer öğretim üyesinin görüşleri alınarak ölçeğin Türkçe formuna son biçimi verilmiştir. Bu aşamaların tamamlanması ile dilsel, kültürel, yapısal ve içerik bakımından uygunluğuna yönelik değerlendirmeler tamamlanmıştır.

Yapılan düzenlemelerin ardından ölçek Likert formatta düzenlenerek pilot uygulamaya hazır hale getirilmiştir. Ölçeğin anlaşılırlığının ve uygulama süresinin belirlenmesi açısından pilot çalışma olarak ortaokul beşinci sınıf öğrencilerine uygulanmıştr. Bu işlem sonrasında öğrencilerin mühendislikle ilgili maddeleri anlamakta güçlük çektikleri belirlendiğinden yönergeye mühendislik mesleğine ilişkin açıklayıcı bir cümle eklenmiştir. Son olarak ölçek biçimsel olarak düzenlenerek uygulamaya hazır hale getirilmiştir. Ölçek öncelikle 202 ortaokul öğrencisine uygulanmış ve bu öğrencilerden elde edilen veriler üzerinden ölçeğin yapısal boyutlarını ortaya koymak amacı ile Açımlayıcı Faktör Analizi (AFA) yapılmıştır. Bu analiz sonucunda elde edilen yapının uygunluğunu test etmek amacı ile ölçek 673 öğrenciye tekrar uygulanmış ve Doğrulayııı Faktör Analizi (DFA) yapılmıştır. Yapı geçerliğini saptamak için yapılan AFA ve DFA çalışmaları bağımsız örneklemler üzerinde gerçekleştirilmiştir.

\section{Verilerin Analizi}

Her iki örneklem grubundan toplanan verilerde, ilk olarak eksik ve hatalı veri girişi olup olmadığı incelenmiştir. İncelemede AFA verileri için 3838 hücreden hiçbirinde; DFA verileri için ise 12785 hücreden 24 tanesinde öğrenciler tarafindan boş bırakılan madde olduğu belirlenmiştir. Bu eksik verilerin rastgele mi yoksa belirli bir yapıya göre mi olduğu incelenmiş ve rastgele dağııım gösterdiği tespit edilmiştir. Eksik verilerin toplam veri sayısına oranı 1/20'den düşük olduğundan düzeltilmesi için her madde için seri ortalama puanının atanması yapılmıştı (Hair, Anderson, Tatham ve Black, 1998). Daha sonra verilerde aykırı (outlier) değerler olup olmadığı incelenmiştir. Örneklem sayısı her iki veri seti için 120 'den büyük olduğundan bu değerlerin düzeltilmesinde $Z$ puanı yöntemi kullanılmıştr. DFA veri setinde iki öğrencinin verileri ortalamanın üç Z puanından yüksek olduğundan analize dâhil edilmemiştir (Seo, 2006). Çünkü cevaplarında uç değer bulunan bireylerin puanları, faktör çözümlerinde yüksek etkiye sahip olduğundan veri dosyasından silinerek bu hatadan arındırıması önerilmektedir (Tabachnick ve Fidell, 2014). Bu iki öğrencilerin verilerinin çıkarılması ile DFA örneklemi 671 öğrenciye düşmüştür.

Eksik verilerin veya aşırı değerlerin düzeltilmesi işleminden sonra faktör analizi için verilerin normalliğinin belirlenmesi amacıyla çarpıklık ve basıklık değerleri incelenmiştir. Test ortalaması üzerinden yapılan işlem sonunda çarpıkık katsayısının 0.68; basıklık katsayısının ise 0.08 olduğu tespit edilmiştir. Bu sonuçlar da verilerin normal dağılım gösterdiğini ve veriler üzerinde parametrik istatistiklerin uygulanabileceğini göstermektedir (Büyüköztürk, 2010). Bu işlemlerden sonra ölçme aracından toplanan verilerin geçerlik ve güvenirlik düzeyine ilişkin çalışmalar gerçekleştirilmiştir.

\section{Bulgular}

Bu bölümde SEYUH ölçeğinin geçerlik ve güvenirlik düzeylerini belirlemek amacıyla yapılan istatistiksel analiz sonuçlarına yer verilmiştir.

\section{AFA ile Ölçeğin Yapı Geçerliğine ilişkin Bulgular}

Çalışmada örneklemden toplanan verilere ilişkin ilk olarak AFA yapılmıştr. Bu analizin aşamaları şu şekildedir:

- Problem tanımlanır ve veriler toplanır.

İlgili ölçek ülkemizde son yıllarda ilgi çeken konulardan biri olan STEM ile ilgili umut ve hedef düzeyini belirlemek amacıyla kullanılacaktır. Bu kapsamda veriler 3 farklı ildeki 6 tane ortaokulda öğrenim gören 202 öğrenciden toplanmıştır.

- Verinin faktör analizine uygunluğu test edilir.

Bu aşamada ilk olarak maddeler arasındaki korelasyon tablosu incelenmiştir. Her maddenin diğer maddelerle ilişkisinde $0.10^{\prime}$ dan küçük ve $0.90^{\prime}$ dan büyük değerler olup olmadığı kontrol edilmiş ve tüm korelasyon katsayılarının bu aralıkta olduğu tespit edilmiştir.

İkinci olarak Kaiser-Mayer-Olkin (KMO) ve Barlett'in Küresellik (Barlett's Test of Sphericity-BTS) Testlerinin sonuçlarına bakılmıştır. KMO değerinin 0.50 'den büyük olması faktör analizinin yapılabileceğini gösterirken 0.50 'den küçük olması, toplanan verilerin faktör analizi için uygun olmadığı anlamına gelmektedir. Bu çalışmanın verileri için KMO değeri 0.81 olarak belirlenmiştir. Field (2005) tarafindan yapılan sınıflandırmada 0.80 ile 0.90 arasındaki değerin faktör analizi yapmak için çok iyi olduğu belirtilmiştir. Buna göre, örneklemden toplanan verilerin faktör analizine uygun olduğu ve yapılan analizlerin güvenilir sonuçlar verdiği söylenebilir. 
Toplanan verilerin faktör analizine uygun olup olmadığını belirlemek için incelenen ikinci özellik BTS sonuçlarıdır. BTS'ye göre, toplanan verilerin sonuçlarının anlamlılık düzeyi 0.05 'den küçük olduğunda faktör analizi için uygun olduğu belirtilmektedir (Büyüköztürk, 2010). Araştrma verilerinin BTS sonuçlarına yönelik ki-kare değerinin anlamlı olduğu belirlenmiştir $\left(\chi^{2}(153)=2002.29 ; p<.01\right)$. Bu da ölçme aracı ile ölçülen değişkenlerin birbiri ile ilişkisinin olduğunu göstermektedir. Hem KMO hem de BTS sonuçları, verilerin çok değişkenli normal dağılımdan geldiğini ve incelenen değişkenler arasında faktör analizi yapmaya yeterli bir ilişki bulunduğunu göstermektedir.

Bu aşamada ayrıca maddelerin anti-imaj korelasyon değerleri incelenmiştir. Field (2005) değişkenler için örneklem uygunluk ölçüsünün 0.50 'den küçük olması durumunda analizin tekrarlanması gerektiğini ifade etmiştir. Aşağıdaki tabloda maddeler arasındaki anti-imaj korelasyon değerleri verilmiştir:

Tablo 2. Maddeler arasındaki anti-imaj korelasyon değerleri

\begin{tabular}{|c|c|c|c|c|c|c|c|c|c|c|c|c|c|c|c|c|c|c|}
\hline Madde & 1 & 2 & 3 & 4 & 5 & 7 & 8 & 9 & 10 & 11 & 12 & 14 & 15 & 16 & 17 & 18 & 19 & 20 \\
\hline Anti-imaj katsayısı & 0.87 & 0.90 & 0.79 & 0.80 & 0.86 & 0.66 & 0.81 & 0.87 & 076 & 0.79 & 0.88 & 0.71 & 0.74 & 0.79 & 0.82 & 0.84 & 0.82 & 0.86 \\
\hline
\end{tabular}

Tabloda görüldüğü gibi, maddelerin anti-imaj korelasyon katsayıları 0.66 ile 0.90 arasında değişmektedir. Bu sonuçlar da verilerin faktör analizine uygunluğu için önemli bir kanıt olarak kabul edilmiştir.

Faktör analizi yapılarak ele alınan değişkenin temel bileşenlerinin nelerden oluştuğuna ilişkin kanıtlar toplanır.

AFA'nın amacı, $p$ tane değişkenin bir araya getirilmesi ve bu değişkenler arasındaki ilişkinin belirlenerek kuramsal olarak birbiri ile ilişkili daha az sayıda değişken (faktör) ortaya çıkarmaktır (Field, 2005). Erkuş (2003) başka kültürlerde geliştirilen bir ölçeğin uyarlanmasında hem kültürel boyutun hem de ölçülen özelliklerin niteliğini ortaya çıkarmak için AFA'nın yapılmasının gerekli olduğunu belirtmiştir. Bu amaçla ölçeğin faktör yapısını belirlemek için ilk olarak döndürülmemiş temel bileşenler analizi yapılmıştır (Tabachnick ve Fidell, 2014). Bu aşamada her bir faktörün öz-değerleri incelenmiş ve öz değeri 1.00'den büyük dört faktör olduğu belirlenmiştir. Öz-değerlere göre meydana gelen faktör sayısının test edilmesi için yamaç eğim grafiğine bakılmıştır. Aşağıda verilen yamaç eğim grafiği, ölçeğin muhtemel faktör yapısını göstermektedir:

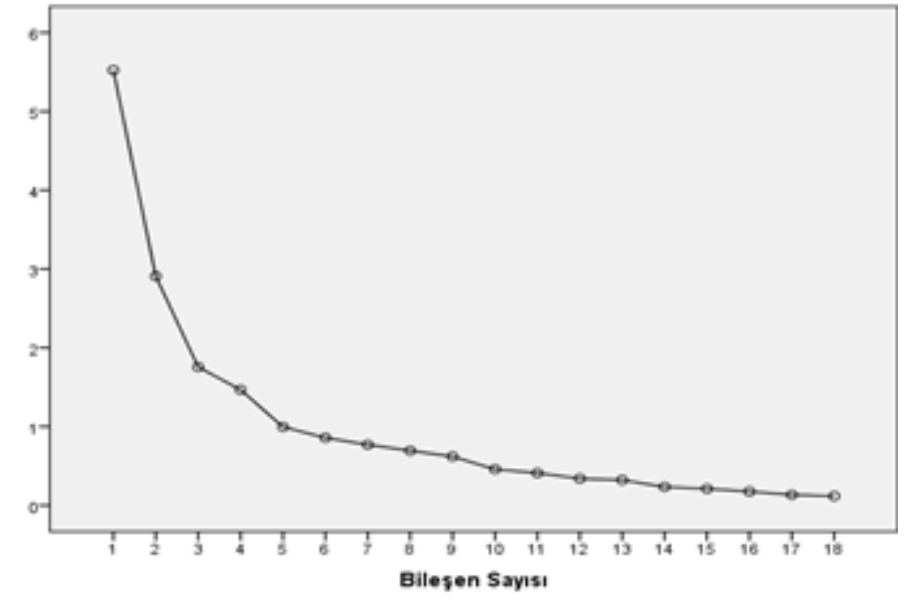

\section{Şekil 2. Özdeğer grafiği}

Yukarıdaki grafik, ölçeğin faktör yapısı hakkında öz-değerin yanında kanıt olabilecek bilgiler sağlamaktadır (Yaman, 2016). Bu grafikler özellikle 200'den büyük örneklemlerde öz-değerden daha güçlü bir kanıt olarak kabul edilmektedir (Field, 2005). Grafikte görüldüğü gibi eğimdeki ilk belirgin kırılma dördüncü bileşenden önce meydana gelmiştir. Buna göre ölçme aracının dört faktör üzerine kurulabileceği ileri sürülebilir. Bu durumu test etmek için rotasyon yöntemlerinden Varimax ve Temel Bileşenler Analizi (Principal Component Analysis) yöntemleri kullanılmıştr. Bu analizler sonunda ölçeğin maddelerinin faktör yük değerleri incelenmiştir. Temel bileşenler analizi bir veri setindeki azami varyansı ortaya koymayı hedefleyen ve genellikle en sık kullanılan faktörleşme tekniklerinden biridir (Tabachnick ve Fidell, 2014). Varimax dikey döndürme tekniği ise maksimum varyans sağlayacak şekilde döndürme yaparak ve faktör matrisi sütunlarındaki değerleri sıfira ve bire yaklaştırarak faktör yapısının ortaya çıkarıımasını sağlamaktadır (Çokluk, Şekercioğlu ve Büyüköztürk, 2012). 
Tablo 3. Ölçek maddelerine ilişkin faktör yük değerleri ve betimsel istatistik sonuçları

\begin{tabular}{|c|c|c|c|c|c|c|}
\hline Maddeler & Faktör1 & Faktör2 & Faktör3 & Faktör4 & $\overline{\mathrm{X}}$ & $S$ \\
\hline 1. Liseden mezun olacağım. & .45 & & & & 4.30 & 1.21 \\
\hline 2. Bir ödeve takılıp kaldığımda bu durumu çözmeye çalışırım. & .46 & & & & 4.01 & 1.00 \\
\hline 3. Üniversiteye gideceğim. & .68 & & & & 4.42 & 1.01 \\
\hline 4. Liseyi bitiremeyebilirim. * & .73 & & & & 4.24 & 1.24 \\
\hline 5. Yetişkin olduğumda mesleğimi seveceğim. & .73 & & & & 4.39 & .93 \\
\hline 7. Meslek sahibi olduğumda yeterince para kazanabileceğim. & .64 & & & & 4.22 & .86 \\
\hline 8. Gelecekteki mesleğimden hoşlanacakmışım gibi görünüyor. & .68 & & & & 4.34 & .98 \\
\hline $\begin{array}{l}\text { 9. Okuldaki sıkı çalışmam, gelecekteki sevdiğim mesleğe ulaşmamı } \\
\text { sağlayacak. }\end{array}$ & .46 & & & & 4.20 & 1.08 \\
\hline 10. Fen ile ilgili bir mesleğe sahip olmak heyecan verici olurdu. & & .87 & & & 3.30 & 1.27 \\
\hline 11. Fen öğrenmek heyecan vericidir. & & .86 & & & 3.59 & 1.30 \\
\hline 12. Fen konularını öğrenmekten keyif alırım. & & .85 & & & 3.65 & 1.21 \\
\hline 14. Mühendislik konularını öğrenmekten keyif alırım. & & & .90 & & 3.40 & 1.22 \\
\hline 15. Mühendislik konularını öğrenmek heyecan vericidir. & & & .90 & & 3.39 & 1.19 \\
\hline 16. Bir mühendis olmak heyecan verici olurdu. & & & .87 & & 3.50 & 1.16 \\
\hline 17. Mühendislik konularında yetenekliyimdir. & & & .66 & & 2.97 & 1.23 \\
\hline 18. Matematik konularını öğrenmekten keyif alırım. & & & & .86 & 3.73 & 1.44 \\
\hline 19. Matematik konularında yetenekliyimdir. & & & & .88 & 3.60 & 1.37 \\
\hline 20. Matematikle uğraşacağım bir işte çalışmak heyecan verici olurdu. & & & & .88 & 3.61 & 1.42 \\
\hline
\end{tabular}

* Negatif anlamlı madde

Tablo 3'e göre ölçek dört faktörden oluşmaktadır. Ayrıca ortak faktör varyans değerleri, orijinal ölçekte yer alan 18 maddenin faktör analizine katlabileceğini göstermektedir. Orijinal ölçekte yer alan 13. madde (bir bilim insanı olmak heyecan verici olurdu) hem birinci hem de dördüncü faktörlere yüklendiğinden ve faktör yük değerleri arasındaki fark .10'dan küçük olduğundan analizlerden çıkarılmıştr. Çünkü bir madde yalnızca bir özelliği ölçmeli ve birden fazla faktörde binişiklik göstermemelidir (Çokluk, Şekercioğlu ve Büyüköztürk, 2012). Analiz sonuçlarına göre birinci faktörde 8 , ikinci faktörde 3, üçüncü faktörde 4 ve dördüncü faktörde 3 maddenin yer aldığı belirlenmiştir. Bu sonuç, ölçme araçlarında bir faktörde en az 3 madde bulunması koşulunun sağlandığını göstermektedir (MacCallum, Widaman, Zhang ve Hong, 1999). Bunun yanında, madde sayısı yüksek faktör yük değerleriyle birlikte faktörlerin kararlılığı açısından güçlü bir kanıtttr (Hogarty, Hines, Kromrey, Ferron ve Mumford, 2005). Comrey ve Lee (1992) faktör yük değerleri için şu aralıkların dikkate alınması gerektiğini ifade etmişlerdir: 0.70 ve üzeri=mükemmel; 0.63 ile 0.70 arası=çok iyi, 0.55 ile 0.62 arası=iyi, 0.45 ile 0.54 arası=normal ve 0.32 ile 0.44 arası=kötü düzeydir. Faktör yük değerleri incelendiğinde 11 maddenin mükemmel, 4 maddenin çok iyi ve 3 maddenin normal faktör yüküne sahip olduğu tespit edilmiştir. Maddelerin yüklendiği faktörler ve bu faktörlerin varyanslarına ilişkin veriler aşağıdaki tabloda sunulmuştur:

Tablo 4. Ölçeğin alt faktörlerine ilişkin varyans sonuçları

\begin{tabular}{lcccc}
\hline Faktörler & Madde Sayısı & Maddeler & Öz-değer & Açılanan Varyans \\
\hline Faktör1 & 8 & $1-2-3-4-5-7-8-9$ & 5.53 & 30.69 \\
Faktör2 & 3 & $10-11-12$ & 1.47 & 8.15 \\
Faktör3 & 4 & $14-15-16-17$ & 2.91 & 16.16 \\
Faktör4 & 3 & $18-19-20$ & 1.76 & 9.76 \\
\hline Toplam & 18 & 18 & 11.67 & 64.77 \\
\hline
\end{tabular}

Tablo 4'e göre SEYUH ölçeğini meydana getiren beş faktörün toplam varyansın yaklaşık \%65'lik kısmını açıkladığı tespit edilmiştir. En yüksek varyans birinci faktöre, en düşük faktör ise ikinci faktöre aittir. Bu analizlerin sonucuna göre birinci faktör "okulda öğrenme ve iş doyumu umudu", ikinci faktör "fene yönelik tutum", üçüncü faktör "mühendisliğe yönelik tutum" ve dördüncü faktör "matematiğe yönelik tutum" olarak isimlendirilmiştir. Faktörler arasındaki ilişki düzeyi aşağıdaki tabloda verilmiştir: 
Tablo 5. Ölçeğin alt boyutları arasındaki korelasyon katsayıları

\begin{tabular}{lccc}
\hline Faktör & Faktör2 & Faktör3 & Faktör4 \\
\hline Faktör1 & .43 & .03 & .41 \\
Faktör2 & & .21 & .45 \\
Faktör3 & & & .23 \\
Faktör4 & & & \\
\hline
\end{tabular}

Tablo 5'deki değerlere göre ölçme aracının alt faktörleri arasında farklı düzeylerde ilişki olduğu belirlenmiştir. En yüksek ilişkinin ikinci faktörle dördüncü faktör $(r=.45 ; p<.01)$ arasında; en düşük ilişkinin ise birinci faktörle üçüncü faktör arasında ( $r=.00 ; p>.05)$ olduğu tespit edilmiştir. Bu sonuçlar, ölçme aracının alt faktörleri arasındaki ilişkinin Büyüköztürk (2002) tarafindan yapılan sınıflandırmaya göre orta ve düşük düzeylerde olduğunu göstermektedir. Büyüköztürk'e göre .00-.29 arası düşük; .30-.69 arası orta; .70-1.00 arası yüksek ilişki söz konusudur.

Ölçme aracının yapı geçerliğinin belirlenmesinde faktör analizi dışında test-madde korelasyonu, karşıt gruplar yöntemi ve çoklu matriks gibi farklı yöntemler de kullanılabilmektedir. Aşağıdaki tabloda bu amaçla yapılmış karşıt gruplar yönteminin bulguları sunulmuştur. Bu yöntem puanlar büyükten küçüğe veya küçükten büyüğe doğru sıralandıktan sonra en yüksek ve en düşük puanlara sahip alt ve üst gruplardaki \%27'lik öğrencilerin puanları arasındaki farklılığın bağımsız gruplar t-testi ile karşılaştırılması ile yapılır (Yaman, 2016). Alt ve üst gruplar arasındaki fark ne kadar büyük olursa ölçme aracının yapı geçerliği için, zayıf da olsa, bir kanıt olarak kabul edilmektedir.

Tablo 6. Karşıt gruplar yöntemine ilişkin bağımsız gruplar için bağımsız gruplar için t-testi sonuçları

\begin{tabular}{|c|c|c|c|c|c|c|c|}
\hline Faktörler & Grup & $\mathrm{N}$ & $\overline{\mathrm{X}}$ & $S$ & $\mathrm{sd}$ & $\mathrm{t}$ & $p$ \\
\hline \multirow{2}{*}{ Faktör1 } & Üst & 55 & 4.74 & .76 & 108 & 10.48 & .000 \\
\hline & Alt & 55 & 3.61 & .25 & & & \\
\hline \multirow{2}{*}{ Faktör2 } & Üst & 55 & 4.53 & .51 & 108 & 14.10 & .000 \\
\hline & Alt & 55 & 2.32 & 1.05 & & & \\
\hline \multirow{2}{*}{ Faktör3 } & Üst & 55 & 4.10 & .70 & 108 & 8.38 & .000 \\
\hline & Alt & 55 & 2.79 & .92 & & & \\
\hline \multirow{2}{*}{ Faktör4 } & Üst & 55 & 4.60 & .55 & 108 & 13.21 & .000 \\
\hline & Alt & 55 & 2.25 & 1.20 & & & \\
\hline \multirow{2}{*}{ Toplam } & Üst & 55 & 4.54 & .20 & 108 & 26.13 & .000 \\
\hline & Alt & 55 & 2.98 & .39 & & & \\
\hline
\end{tabular}

Tablo 6'ya göre alt ve üst gruplarda yer alan öğrencilerin puanları arasında hem toplam puan hem de dört alt faktör puanları arasında anlamlı düzeyde farklılık olduğu $(p<.01)$ ve bu farklılı̆ın üst gruptaki öğrenciler lehine meydana geldiği tespit edilmiştir. Bu sonuç ölçme aracı ile elde edilen puanların, karşıt gruplar yöntemine göre yapı geçerliğine yönelik bir kanıt olarak kabul edilmiştir. Ayrıca mühendisliğe yönelik tutumun diğer faktörlere göre daha düşük ortalama puana sahip olmasının nedeninin, Türkiye'de mühendisliğin fen bilimleri dersi öğretim programında (MEB, 2018) 2017-2018 eğitim-öğretim yılıyla birlikte girmesi ve bu programın verilerin toplandığı eğitim-öğretim yılında sadece beşinci sınıflarda uygulanmış olması gösterilebilir.

\section{Ölçme Aracının Faktörlerine Yönelik Açıklamalar}

Orijinal ölçek 19 maddeden ve beş alt faktörden meydana gelmiştir. Ölçeğin alt faktörleri sırasıyla "okulda öğrenme umudu", "iş doyumu umudu", "fene yönelik tutum", "matematiğe yönelik tutum" ve "mühendisliğe yönelik tutum" olarak isimlendirilmiştir. Uyarlama çalışmasının sonuçları ise ölçme aracının dört faktöre yüklendiğini göstermektedir. Bu analizler orijinal ölçme aracının birinci ve ikinci faktörlerinin tek faktöre yüklendiğini ortaya koymuştur. Birleşen bu faktörlere "okulda öğrenme ve iş doyumu umudu" ismi verilmiştir. Bu durumun Türkiye'de lise eğitiminin aynı zamanda mesleki yaşama hazırlık açısından kritik bir dönem olarak kabul edilmesinden kaynaklandığı söylenebilir (Vurucu, 2010). Orijinal ölçekte farklı olan fakat bu çalışmada birleşen bu faktörün maddelerinin öğrencilerin bu ilişkiyi kurmalarına uygun olduğu ifade edilebilir. Örneğin; "Üniversiteye gideceğim" maddesi ile meslek yaşamının temellerine adım atan öğrenci "Yetişkin olduğumda mesleğimi seveceğim" maddesi ile de liseden sonraki yaşamını ilişkilendirmiş olabilir. Bu faktör, öğrencilerin okulda aldıkları eğitime yönelik umutları yanında gelecekte yapabilecekleri mesleklere yönelik umutlarını da kapsamaktadır. 
Uyarlanan ölçeğin 13. maddesi, orijinal ölçekte "fene yönelik tutum" faktörü altına yüklenmiş olmasına rağmen bu çalışmanın sonuçlarına göre "mühendisliğe yönelik tutum" faktörüne yüklenmiştir. Bu durum, öğrencilerin bir bilim insanı olmayı mühendislik mesleğiyle daha fazla ilişkilendirmelerinden kaynaklandığı şeklinde açıklanabilir. Doğan Bora, Arslan ve Çakıroğlu (2010), lise öğrencileri ile yürüttükleri çalışmada lise öğrencilerinin bilim insanını genellikle icat yapan, buluş üreten kişiler olduğu belirtmiş ve örneğin erkek bilim insanlarının tıraş makinesi, kadın bilim insanlarının ise selüloit kremi gibi şeyler üretebileceği örneklerini vermişlerdir. Bu açıdan bilim insanlarını mühendislik mesleği ile ilişkilendirmiş olabilecekleri düşünülmektedir. AFA ile belirlenen bu faktör yapısı bulguları, DFA sonucunda ortaya çıkan yapı ile örtüşmektedir.

\section{DFA}

DFA ile bir veri setinin uyum iyiliğinin belirlenmesinde birçok indeks kullanılabilmektedir. Büyüköztürk ve ark. (2004), uyum indekslerinin birbirlerine göre güçlü ve zayıf yönleri olduğunu; bu nedenle DFA için birden fazla indeksin kullanılmasının yararlı olacağını ifade etmişlerdir. DFA analizlerinde en fazla tercih edilen uyum indekslerine ilişkin açıklamalar aşağıda verilmiştir:

a) Ki-kare (Chi-square- $\chi 2$ ) uyum indeksi: Yapısal eşitlik modellerinde tüm modelin uygun olup olmadığını test etmek için kullanılan en yaygın ve geleneksel indekslerden biridir (Raykov ve Marcoulides, 2006). Bu indeksin değeri 0.00'a yaklaştikça veri toplanan örneklemin evrene uyumunun yüksek olduğu kabul edilmektedir (Schumacker ve Lomax, 2010). Örneklem sayısından en fazla etkilenen indekslerden biri olduğundan, özellikle 200 ve üzeri örneklemlerde $p$ değerinin 0.00’a yaklaşma olasılığı da yüksektir (Kline, 2016). Bu araştırmada 671 öğrenciden veri toplandığından elde edilen indeksin, evreni temsil etme gücünün yüksek olduğu söylenebilir.

b) $\chi 2 / s d$ (Ki-kare/serbestlik derecesi): Serbestlik derecesinin uyum indeksleri üzerinde önemli bir etkisi vardır. Bu değerin ki-kare değerine oranı, iyi uyum indeksleri arasında kabul edilmektedir. Bu oranın 2'nin altında olması tercih edilmekle birlikte 5'in altndaki değerlerin de yeterli olduğu ifade edilmektedir (Hooper, Coughlan ve Mullen, 2008).

c) Örneklem Büyüklüğ̈̈ (Simple size): Modelin uygunluğu üzerinde önemli parametrelerden biridir. Örneklemin evreni temsil edebilirliğinin yüksek olması için veri sayısının en az 200 olması gerektiği; bu sayının altındaki modellerin uygun olmayacağı ve reddedilmesi gerektiği ifade edilmektedir (Barrett, 2007). Bu çalışmada DFA için 671 öğrenciden veri toplandığından, yeterli örneklem büyüklüğünün sağlandığını kabul edilmiştir.

c) GFI (Goodness of fit index-Uyum iyiliği indeksi): En genel ifade ile açıklanan genelleştirilmiş varyansın toplam genelleştirilmiş varyansa oranını vermektedir (Hooper, Coughlan ve Mullen, 2008). Bu araştırmanın sonuçlarında görüldügü gibi (.92), GFI değerinin 0.90'ın üzerinde olması, denenen modelin uygunluğu için önemli bir delil olarak kabul edilmektedir (Munro, 2005). Bu indeks de ki-kare gibi örneklem büyüklüğünden etkilendiğinden, bu çalışmada yer alan veri sayısının elde edilen değer üzerinde olumlu katkı sağladığı söylenebilir (Sharma, Mukherjee, Kumar ve Dillon, 2005).

d) CFI (Comparative fit index-Karşılaştırmalı uyum indeksi): Bentler tarafindan 1990 yılında geliştirilen bu indeks, küçük örneklemlerde bile etkili sonuçlar vermektedir (Tabachnick ve Fidell, 2014). Bu çalışmada elde edilen .92 değerinin iyi uyum için önemli bir kanıt olduğu kabul edilmektedir (Bentler, 1990).

e) RMR (Root mean square residuals-Kök artk kareler ortalaması): Bu indeks özellikle puanları standart olan derecelendirilmiş ölçekler için tercih edilmektedir. Model tarafindan tahmin edilen ve gözlenen kovaryans matriksleri arasındaki farkın büyüklüğüne göre uyumu belirlemek amacıyla kullanılabilmektedir. Bu çalışmanın sonuçlarında görüldüğü gibi (.07) RMR değeri 0.00’a ne kadar yakın olursa uyum düzeyinin o kadar yüksek olduğu kabul edilmektedir (Kline, 2016).

f) RMSEA (Root mean square error of approximation-Yaklaşık hataların ortalama karekökü): Bu indeks, en iyi seçilen parametre tahminleri ile hazırlanan modelin örneklem kovaryans matrisine ne kadar uyacağının güçlü bir göstergesidir (Byrne, 1998). Modeldeki tahmini parametrelerin sayısına yönelik duyarlılığı nedeniyle, en bilgilendirici uyum endekslerinden biridir (Diamantopoulos ve Siguaw, 2000). Bu çalışmada elde edilen .07 değeri dikkate alındığında, bu indekste elde edilecek değerin 0.10 'dan küçük olmasının, modelin iyi uyum gösterdiğine yönelik yeterli bir kanıt olduğu söylenebilir (Barrett, 2007).

Açımlayıc faktör analizi ile belirlenen yapının uygunluğunu test etmek amacı ile 671 öğrenciden toplanan veriler üzerinden doğrulayıcı faktör analizi gerçekleştirilmiştir. Analiz sonucunda elde edilen uyum indeksleri Tablo 7'de sunulmuştur: 
Tablo 7. Uyum indeksleri, kabul edilebilir değerler ve araştırmadan elde edilen değerler

\begin{tabular}{llll}
\hline Uyum indeksi & Normal Değer & Kabul edilebilir değer & Araştirma Değerleri \\
\hline$\chi^{2}$ & $p<.05$ & $p<.05$ & .00 \\
$\chi^{2} /$ sd & $<2$ & $<5$ & 3.91 \\
Örneklem sayısı & $>200$ & $>200$ & 671 \\
GFI & $>.95$ & $>.90$ & .92 \\
CFI & $>.95$ & $>.90$ & .92 \\
RMR & $<.05$ & $<.10$ & .07 \\
RMSEA & $<.05$ & $<.10$ & .07 \\
\hline
\end{tabular}

Tablo 7'de yer alan sonuçlar incelendiğinde tüm uyum indekslerinin normal veya kabul edilebilir değer aralığında olduğu görülmektedir. Bu durum DFA analizi sonucunda tespit edilen yapının orta düzeyde uygun olduğu şeklinde yorumlanabilir. DFA analizine ait path diyagramı Şekil 3'te verilmiştir.

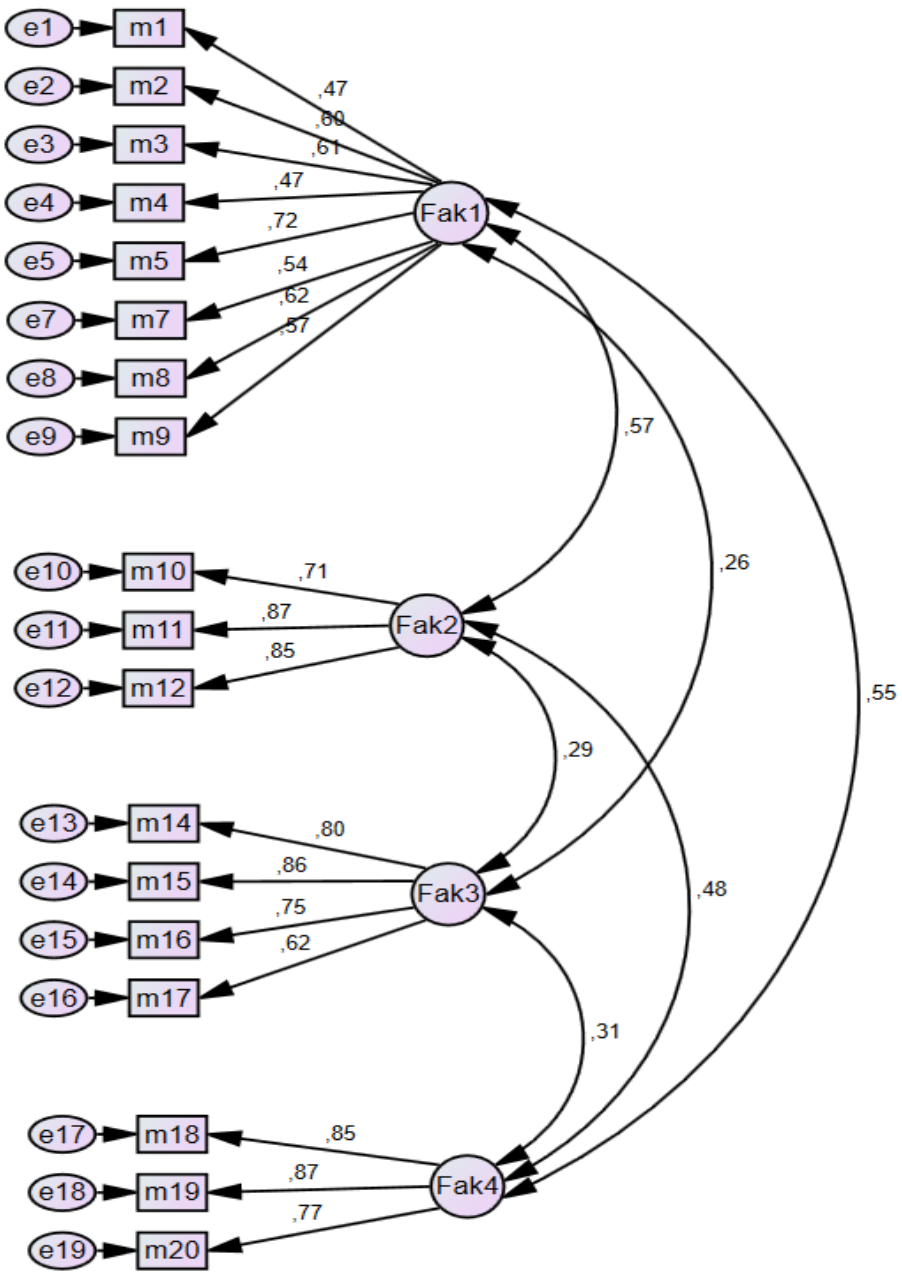

\section{Şekil 3. Doğrulanan modele ilişkin yol (path) diyagramı}

Yukarıdaki şekilde görüldüğü gibi faktörler arasında iki alt faktör arasında düşük (birinci-üçüncü faktör, ikinci-üçüncü faktör); dört faktör arasında ise orta düzeyde (birinci-ikinci faktör, birinci-dördüncü faktör, ikinci-dördüncü faktör ve üçüncü-dördüncü faktör) ilişki vardır. Mühendisliğe yönelik tutumun hem okulda öğrenme ve iş doyumu umudu hem de fen öğrenmeye yönelik tutum arasında düşük ilişkinin görülmesi, verilerin toplandığı zaman fen bilimleri öğretim 
programında mühendislik uygulamaları temasının henüz uygulamaya başlanmaması ile açıklanabilir.

Uyarlanan ölçme aracının güvenirlik düzeyini belirlemek için iki farklı yöntem kullanılmıştı:

\section{İç Tutarlık Katsayısı}

SEYUH ölçeğinin iç tutarlık düzeyini belirlenmek amacıyla Cronbach Alfa katsayısı hesaplanmıştır. Bu katsayı, bileşenlere ait puanların birleşik test puanlarıyla tutarlıı̆ı̆ının bir ölçüsü olarak kabul edilmektedir (Baykul, 2000). $\alpha$ katsayısı bir ölçeğin tamamı ile ölçülmek istenen özelliğine ilişkin alt maddelerin birbirleriyle olan tutarlılı̆ının bir göstergesidir. Bu amaçla ölçme aracı hem AFA hem de DFA örneklemlerine uygulanarak ölçeğin toplam ve alt boyutları için güvenirlik katsayıları hesaplanmıştır. Aşağıdaki tabloda bu güvenirlik katsayıları verilmiştir:

Tablo 8. Ölçme aracının genel ortalama puanının güvenirlik katsayısı ve her bir alt boyuta ilişkin güvenirlik katsayıları

\begin{tabular}{lccc}
\hline \multicolumn{1}{c}{ Faktörler } & Madde sayısı & $\begin{array}{c}\text { AFA örneklemi için } \\
\text { Cronbach alfa katsayıları }\end{array}$ & $\begin{array}{c}\text { DFA örneklemi için } \\
\text { Cronbach alfa katsayıları }\end{array}$ \\
\hline Faktör 1 & 8 & .79 & .80 \\
Faktör 2 & 3 & .91 & .85 \\
Faktör 3 & 4 & .87 & .84 \\
Faktör 4 & 3 & .92 & .87 \\
\hline Toplam & 18 & .86 & .87 \\
\hline
\end{tabular}

\section{Test-Tekrar Test Güvenirliği}

SEYUH ölçeğinin kararlılık düzeyini belirlemek amacıyla AFA ve DFA örnekleminden toplanan veriler için test-tekrar test yöntemi kullanılmıştır. Bu yöntem ile ölçme aracı ile toplanan verilerin ne ölçüde tutarlı oldukları test edilmektedir (Erkuş, 2003). iki farklı örneklem grubundaki öğrenciler sınıf düzeyi ve yaş özellikleri bakımından benzer olduklarından elde edilen verilerin, ölçme aracının kararlılık düzeyini ortaya çıkardığı kabul edilmiştir. Bu amaçla iki veri seti arasındaki Pearson Momentler Çarpım Korelasyon Katsayısı hesaplanmıştır. Bu işlemde AFA örnekleminde yer alan 202 öğrenci olduğundan, DFA örnekleminden rastgele seçilen 202 öğrencinin verileri karşılaştırılmıştır. Bu işlem sonunda ölçme aracının iki uygulaması arasında yüksek düzeyde pozitif ve anlamlı bir ilişki olduğu meydana geldiği tespit edilmiştir $(r(202)=.95, p<.05)$.

\section{Sonuçlar ve Öneriler}

Ölçme işlemi, bir veya birden çok özelliğin gözlemlenerek bu gözlemlerin sayı ve sembollerle ifade edilmesi sürecidir. Bu süreçteki ölçümler doğrudan veya dolaylı olabilir (Tekin, 1991). Doğrudan ölçümlerin ölçülmesi, dolaylı ölçümlere göre daha kolaydır. Çünkü insanlara yönelik dolaylı ölçümler, daha çok gösterdikleri tepkilere göre yapılabilmektedir. Öğrenmeye yönelik birçok özellik dolaylı şekilde ölçülebildiğinden, bu süreçte gözlemler, görüşmeler veya insanların kendilerine yöneltilen maddelere verdikleri tepkiler önem kazanmaktadır. Psiko-motor beceriler daha çok gözlemlerle belirlenebilirken bilişsel ve duyuşsal özelliklerin ölçülmesinde en fazla kullanılan araçlar, psikolojik testler olarak da bilinen ölçeklerdir. Psikolojik özelliklerin ölçülmesinde kullanılan bütün araçlar dinamik bir yapıdadır ve bu araçları kullanarak yapılan her bir araştırmanın psikometrik özelliklerin daha da belirginleşmesine katkı sağlayacağı beklenmektedir (Bozanoğlu, 2004). Bu araştırmada Türkçeye uyarlanan SEYUH ölçeği, öğrencilerin duyuşsal becerilerini ortaya çıkarmak amacını gütmektedir.

Araştrrma sonunda, SEYUH ölçeğinin hem geçerlik hem de güvenirlik yönünden yeterli düzeyde olduğu belirlenmiştir. Orijinal ölçekte beş faktör ve 19 madde olarak belirlenen araç, uyarlama çalışması sonunda 18 madde ve dört faktörlü bir yapıda ortaya çıkmıştr. Orijinal ölçekte "okulda öğrenme umudu" ve "iş doyumu umudu" faktörleri bu çalışmada bir faktör altnna toplanmış ve "okulda öğrenme ve iş doyumu umudu" olarak isimlendirilmiştir. Orijinal ölçekteki "bir bilim insanı olmak heyecan verici olurdu" maddesi, iki farklı faktöre birden yüklendiğinden ve faktör yük değerleri arasındaki fark .10'dan küçük olduğundan uyarlanan ölçekten çıkarılmıştr. AFA ile ortaya çıkarılan sonuçlar DFA ile de doğrulanmış ve uyum indeksleri ölçeğin kabul edilebilir düzeyde sonuçlar verdiğini göstermiştir. Uyarlanan ölçeğin güvenirlik düzeyi ise AFA örneklemi için .86; DFA örneklemi için .87 çıkmış ve bu sonuçlar ölçeğin tutarlılık düzeyinin yüksek olduğunu göstermiştir.

Toplanan verilerin analiz sonuçları, bu çalışmanın yöntem kısmında model-veri uyumu açısından kabul edilebilir bir yapıyı ölçmede yeterli özelliklere sahip olduğunu göstermektedir. Bu sonuçlara göre, ölçeğin ortaokul öğrencilerinin STEM eğitimine yönelik umut ve hedeflerinin belirlenmesi amacıyla kullanılabileceğini göstermektedir. STEM'in kavram

| Kastamonu Eğitim Dergisi, 27(3), 2019| 
olarak ülkemizde yeni olması, öğretim programlarına 2018 yılında dahil edilmesi ve bu konudaki çalışmaların ağırlıklı olarak yabancı kaynaklı olması, araştırmanın bir sınırılı̆̆ı olarak kabul edilmiştir. Ayrıca, ölçme aracının gelecekte daha farklı eğitim kademlerinde (ilkokul, lise ve üniversite) uygulanmasının varyansı daha geniş ve daha büyük örneklemlere ulaşııması ile bu araştırmanın sonuçlarının genellenebilirliğinin de artacağı ileri sürülebilir. Farklı modellerin kullanıldığı ve farklı analiz yöntemlerinin uygulandığı çalışmalarla ölçme aracının faktör yapısının yeniden incelenmesinin yararlı olacağı düşünülmektedir. Bu kapsamda öğrencilerin birbiri ile korelasyon gösteren özelliklerinin inceleneceği bir deneysel modelin kullanılması, ölçme aracının sonuçlarının faktör yapısı ve güvenirlik düzeyine yönelik daha açık kanıtlar sağlayabilir.

Bu çalışma kapsamında uyarlanan, geçerlik ve güvenirlik analizleri yapılan SEYUH ölçeğinin, son yıllarda dünyada olduğu kadar ülkemizde de popüler olan ve öğretim programlarına giren STEM konusunda yapılacak çalışmalarda yol gösterici ve belirleyici olacağı düşünülmektedir. Bu ölçeğin araştrrmacılar, öğretmenler ve STEM'in en fazla etkilenmesi beklenen öğrencilerin duyuşsal boyutları açısından yararlı bilgiler elde etmede kullanılabileceği düşünülmektedir. Öğrenmenin bilişsel boyutu çok önemli olmakla birlikte, duyuşsal boyut dikkate alınmadan yapılacak bir öğretimin veya öğrenmenin mümkün olmadığı kabul edilmektedir (Özden, 2002). STEM ile ilgili öğrenmelerde bu duyuşsal ve bilişsel becerilerin birbirlerini ne kadar ve nasıl etkilediği konusunda yeni araştırmalara gereksinim vardır. Bu araştrmalar sonucunda STEM eğitimi konusunda belirlenen hedeflerin gerçekleşme düzeyine ilişkin kuramsal bir çerçeve oluşması beklenebilir.

Yukarıdaki açıklamalar ışığında, SEYUH ölçeğinin, ortaokul düzeyinde öğrenim gören öğrencilerin bu becerilerini ölçmek amacıyla kullanılabileceği söylenebilir. Tüm analiz sonuçları, ölçme aracının geçerlik ve güvenirlik düzeyinin yeterli olduğunu ve dört faktör ile belirlenen yapıyı açıklayabildiğini göstermektedir. Öğrencilerin okulda öğrendikleri bilgilere ve farklı disiplinlere yönelik umut ve hedefleri, bu ölçme aracının çok boyutlu yapısı ile açıklanabilir. Umut ve hedef yanında öğrencilerin fen, matematik ve mühendisliğe yönelik tutumlarını da ölçen bu ölçme aracı ile son yılların en popüler başlıklarından biri olan STEM eğitimine yönelik genel algıları da ortaya çıkarılabilir. Böylece fen bilimleri dersi öğretim programında yer verilen mühendislik uygulamaları ve bu uygulamaların temelini oluşturan STEM eğitimi için önemli veriler elde edilebilecektir.

\section{Kaynakça}

Akgündüz, D., Aydeniz, M., Çakmakçı, G., Çavaş, B., Çorlu, M. S., Öner, T., \& Özdemir, S. (2015). STEM eğitimi Türkiye raporu. İstanbul: Scala Basım. Baenninger, M., \& Newcombe, N. (1989). The role of experience in spatial test performance: A meta-analysis. Sex Roles, 20(6), 327-344.

Bağcı, H., \& Şahbaz, N. K. (2012). Türkçe öğretmeni adaylarının eleştirel düşünme becerileri üzerine bir değerlendirme. Mersin Üniversitesi Eğitim Fakültesi Dergisi, 8(1), 1-12.

Barrett, P. (2007). Structural equation modelling: Adjudging model fit. Personality and Individual Differences, 42(5), 815-824.

Baykul, Y. (2000). Eğitimde ve psikolojide ölçme. Ankara: ÖSYM Yayınları.

Bozanoğlu, İ. (2004). Akademik güdülenme ölçeği: Geliştirmesi, geçerliği, güvenirliği. Ankara Üniversitesi Eğitim Bilimleri Fakültesi Dergisi, 37(2), 83-98.

Byrne, B. M. (1998), Structural equation modeling with LISREL, PRELIS and SIMPLIS: Basic concepts, applications and programming. Mahwah, New Jersey: Lawrence Erlbaum Associates.

Buyruk, B., \& Korkmaz, Ö. (2016). FeTeMM farkındalık ölçeği (FFÖ): Geçerlik ve güvenirlik çalışması. Türk Fen Eğitimi Dergisi, 13(2), 61-76. doi: 10.12973/tused.10179a

Büyüköztürk, Ş. (2010). Sosyal bilimler için veri analizi el kitabı. Ankara: Pegem Akademi.

Comrey, A. L., \& Lee, H. B. (1992). A first course in factor analysis. (2th Ed.), New Jersey: Lawrence Erlbaum Associates, Publishers, Hillsdale.

Çokluk, Ö., Şekercioğlu, G., \& Büyüköztürk, Ş. (2012). Sosyal bilimler için çok değişkenli istatistik. Ankara: Pegem Akademi.

Diamantopoulos, A., \& Siguaw, J. A. (2000). Introducing LISREL. London: Sage Publications.

Doğan Bora, N., Arslan, O., \& Çakıroğlu, J. (2006). Lise öğrencilerinin bilim ve bilim insanı hakkındaki görüşleri. Hacettepe Üniversitesi Eğitim Fakültesi Dergisi, 31(1), 32-44.

Douglas, K. A., \& Strobel, J. (2015). Hopes and goals survey for use in STEM elementary education. International Journal of Technology and Design Education, 25(2), 245-259.

Erkuş, A. (2003). Psikometri üzerine yazılar. Ankara: Türk Psikologlar Derneği Yayınları.

Field, A. (2005). Discovering statistics using SPSS. London: SAGE Publishing.

Friedman, T. L. (2005). The world is flat. New York: Farrar, Straus, \& Giroux.

Furner, J., \& Kumar, D. (2007). The Mathematics and science integration argument: A stand for teacher education. Eurasia Journal of Mathematics, Science \& Technology, 3(3), 185-189.

Güneş, H., \& Karaşah, Ş. (2016). Geçmişten günümüze fen eğitiminin önemi ve fen eğitiminde son yıllarda yapılan çalışmalar. Eğitim ve Öğretim Araştırmaları Dergisi, 5(3), 122-136. 
Hair, J., Anderson, R., Tatham, R., \& Black, W. (1998). Multivariate data analysis with readings (5th Ed.). Prentice-Hall International Inc.

Hogarty, K. Y., Hines, C. V., Kromrey, J. D., Ferron, J. M., \& Mumford, K. R. (2005). The quality of factor solutions in exploratory factor analysis: The Influence of sample size, communality and overdetermination. Educational and Psychological Measurement, 65, 202-226.

Hooper, D., Coughlan, J., \& Mullen, M. R. (2008). Structural equation modelling: Guidelines for determining model fit. Electronic Journal of Business Research Methods, 6(1), 53-60.

Irving, L. M., Snyder, C. R., \& Crowson, J. J. (1998). Hope and coping with cancer by college women. Journal of Personality, 22, $195-214$.

Karasar, N. (2005). Bilimsel araştırma yöntemi, Ankara: Nobel Yayın Dağı̆tım

Kline, R. B. (2016). Principles and practice of structural equation modeling (4th Ed.). New York: The Guilford Press.

Langdon, D., McKittrick, G., Beede, D., Khan, B., \& Dom, M. (2011). STEM: Good Jobs Now and for the future, U.S. Department of Commerce Economics and Statistics Administration, 3(11), 2-12.

Lubinski, D., \& Benbow, d. (2006). Study of mathematically precocious youth after 35 years: Uncovering antecedents for the development of math-science expertise. Perspectives on Psychological Science, 1(4), 316-345.

MacCallum, R. C., Widaman, K. F., Zhang, S., \& Hong, S. (1999). Sample size in factor analysis. Psychological Methods, 4, 84-99.

MEB (Millî Eğitim Bakanlığı). (2018). Fen bilimleri dersi öğretim programı: ilkokul ve ortaokul 3, 4, 5, 6, 7 ve 8. sınıflar, Erişim tarihi: 23.01.2018, http:// mufredat.meb.gov.tr/ProgramDetay.aspx?PID=325.

Munro, B. (2005). Statistical methods for health care research (5th Ed.). Philadelphia, PA: Lippincott Williams and Wilkins.

Obama, B. (2010). Changing the equation in STEM education. Erişim tarihi: 07.11.2016. https://www.youtube.com/watch?v=5IljiPJQgSU

Özden, Y. (2002). Eğitimde yeni değerler: eğitimde dönüşüm (5. Baskı), Pegem A Yayıncılık, Ankara.

Pawlowski, J. M. (2007). The quality adaptation model: Adaptation and adoption of the quality standard ISO/IEC 19796-1 for learning, education, and training. Educational Technology \& Society, 10(2), 3-16

Raykov T., \& Marcoulides G. A. (2006). Fundamentals of structural equation modeling: A first course in structural equation modeling (2nd Ed). London: Lawrence Erlbaum Associates.

Rideout, E., \& Montemuro, M. (1986). Hope, morale and adaptation in patients with chronic heart failure. Journal of Advanced Nursing, 11(4), 429-438.

Scott, M. C. (2009). Technology education for children council, technology and children. Journal for Elementary School Technology Education, $14(1)$, 3-15.

Seçer, i. (2015). SPSS ve LISREL ile pratik veri analizi. Ankara: Anı Yayıncılık.

Seo, S. (2006). A review and comparison of method for detecting outliers in univariate data sets. Unpublished Master' Thesis, University of Pittsburgh, ABD.

Sharma, S., Mukherjee, S., Kumar, A., \& Dillon, W. R. (2005). A simulation study to investigate the use of cutoff values for assessing model fit in covariance structure models, Journal of Business Research, 58(1), 935-43.

Snyder, C. R., \& Rand, K. L. (2000, August). a question for therapists: Is there false hope? Paper presented at the American Psychological Association Convention, Washington, D.C.

Snyder, C. R., Harris, C., Anderson, J. R., Holleran, S. A., Irving, L. M., ... \& Harney, P. (1991). The will and the ways: development and validation of an individual-differences measure of hope. Journal of Personality and Social Psychology, 60, 570-585.

Snyder, C. R., Irving, L., \& Anderson, J. R. (1991). Hope and health: Measuring the will and ways. In C. R. Snyder \& D. R. Forsyth (Eds.), Handbook of social and clinical psychology: The health perspective (pp. 285-305), Elmsford, NY: Pergamon Press.

Schumacker, R. E., \& Lomax, R. G. (2010). A beginner's guide to structural equation modeling (3rd Ed.). New York: Routledge.

Tabachnick, B.G., ve Fidell, L.S. (2014). Using multivariate statistics (6th Ed). Edinburgh: Pearson Education Limited.

Tekin, H. (1991). Eğitimde ölçme ve değerlendirme. Ankara: Yargı Kitap ve Yayınevi.

TDK (Türk Dil Kurumu). (2017). Büyük Türkçe sözlük. Retrived January 18, 2018, from: http://www.tdk.gov.tr/index.php?option=com_bts\&view=bts.

The White House. (2009, November 23). President Obama launches "educate to Innovate" campaign for excellence in science, technology, engineering \& math (STEM) education. Erişim tarihi: 12.02.2018, Retrieved from http://www.whitehouse.gov/the-press-offce/president-obama-launches-educate-innovate-campaign-excellence-science-technology-en.

Vurucu, F. (2010). Meslek lisesi öğrencilerinin meslek seçimi yeterliliği ve meslek seçimini etkileyen faktörler. Yayınlanmamış Yüksek Lisans Tezi, Yeditepe Üniversitesi Sosyal Bilimler Enstitüsü, i̇stanbul.

Wai, J., Lubinski, D., Benbow, C. P., \& Steiger, J. H. (2010). Accomplishment in science, technology, engineering, and mathematics (STEM) and its relation to STEM educational dose: A 25-year longitudinal study. Journal of Educational Psychology, 102(4), 860.

Yaman, S. (2016). Ortaokul öğrencileri için fen öğrenmeye yönelik öz-yeterlik inanç ölçeği uyarlaması: Geçerlik ve güvenirlik çalışması. İnönü Üniversitesi Eğitim Fakültesi Dergisi, 17(2), 123-140.

Yıldırım, B., \& Altun, Y. (2015). STEM eğitimi üzerine derleme çalışması: Fen bilimleri alanında örnek ders uygulanmaları. M. Riedler et al. (Ed.) in VI. International Congress of Education Research, Ankara, Hacettepe Üniversitesi.

Yılmaz, H., Yiğit-Koyunkaya, M., Güler, F., \& Güzey, S. (2017). Fen, teknoloji, mühendislik, matematik (STEM) eğitimi tutum ölçeğinin Türkçe'ye uyarlanması. Kastamonu Eğitim Dergisi, 25(5), 1787-1800. 


\section{Ek. Ölçme Aracının Eski ve Yeni Madde Numaraları ile Dereceleri}

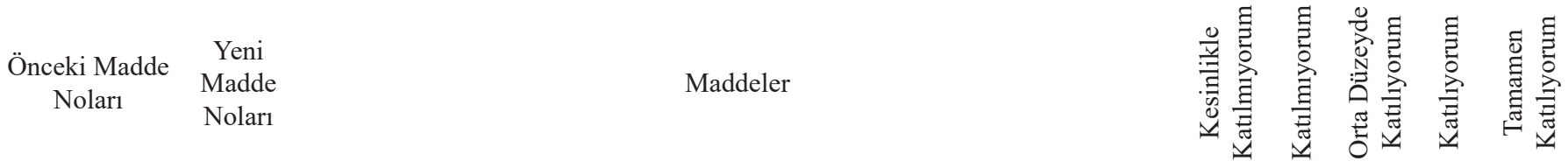

Faktör1: Okulda öğrenme ve iş doyumu umudu

\begin{tabular}{|c|c|c|c|c|c|c|}
\hline 1 & 1 & Liseden mezun olacağım. & 1 & 2 & 3 & 4 \\
\hline 2 & 2 & Bir ödeve takılıp kaldığımda bu durumu çözmeye çalışırım. & 1 & 2 & 3 & 4 \\
\hline 3 & 3 & Üniversiteye gideceğim. & 1 & 2 & 3 & 4 \\
\hline 4 & 4 & Liseyi bitiremeyebilirim.* & 1 & 2 & 3 & 4 \\
\hline 5 & 5 & Yetişkin olduğumda mesleğimi seveceğim. & 1 & 2 & 3 & 4 \\
\hline 7 & 6 & Meslek sahibi olduğumda yeterince para kazanabileceğim. & 1 & 2 & 3 & 4 \\
\hline 8 & 7 & Gelecekteki mesleğimden hoşlanacakmışım gibi görünüyor. & 1 & 2 & 3 & 4 \\
\hline 9 & 8 & Okuldaki sıkı çalışmam, gelecekteki sevdiğim mesleğe ulaşmamı sağlayacak. & 1 & 2 & 3 & 4 \\
\hline
\end{tabular}

Faktör2: Fene yönelik tutum
$1099 \quad$ Fen ile ilgili bir mesleğe sahip olmak heyecan verici olurdu.
$11 \quad 10 \quad$ Fen öğrenmek heyecan vericidir.
$12 \quad 11$ Fen konularını öğrenmekten keyif alırım.

Faktör3: Matematiğe yönelik tutum
1412 Mühendislik konularını öğrenmekten keyif alırım
1513 Mühendislik konularını öğrenmek heyecan vericidir.
1614 Bir mühendis olmak heyecan verici olurdu.
$17 \quad 15$ Mühendislik konularında yetenekliyimdir

Faktör4: Mühendisliğe yönelik tutum

\begin{tabular}{llllllll}
18 & 16 & Matematik konularını öğrenmekten keyif alırım. & 1 & 2 & 3 & 4 & 5 \\
19 & 17 & Matematik konularında yetenekliyimdir. & 1 & 2 & 3 & 4 & 5 \\
20 & 18 & Matematikle uğraşacağım bir işte çalışmak heyecan verici olurdu. & 1 & 2 & 3 & 4 & 5 \\
\hline
\end{tabular}

